\title{
PENGARUH PENGELOLAAN STRESS KELUARGA TERHADAP ACTIVITY DAILY LIVING (ADL) PASIEN POST STROKE ISKEMIK: LITERATURE REVIEW
}

\author{
Lis Mukti Lestari* \\ Fitria Handayani**
}

*) Mahasiswa Magister Keperawatan Konsentrasi Keperawatan Dewasa, Fakultas Kedokteran Universitas Diponegoro, Jl. Prof. H. Soedarto, S.H. Tembalang, Kota Semarang, Jawa Tengah 502705, lismuktil@gmail.com

**) Dosen Keperawatan Dewasa, Fakultas Kedokteran Universitas Diponegoro, Jl. Prof. H. Soedarto, S.H. Tembalang, Kota Semarang, Jawa Tengah 502705, fitriahandayani@undip.ac.id

\begin{abstract}
Abstrak
Asuhan keperawatan pada pasien stroke merupakan rangkaian intervensi yang dilakukan perawat terhadap pasien dan keluarganya. Hasil wawancara yang dilakukan penulis terhadap 10 pasien stroke yang menjalani rawat inap di RSUD Ungaran, pasien mengalami ketidakmampuan dalam melakukan aktifitasnya sehari - hari (ADL), dan keluarga merasa terbebani dari kondisi pasien tersebut. Penulisan artikel ini bertujuan untuk mendeskripsikan pengaruh pengelolaan stress keluarga terhadap kemandirian pasien post stroke iskemik. Metode penulisan ini adalah literature review. Penulisan artikel ini menggunakan sumber pustaka jurnal dan buku referensi dengan kata kunci stress family, stroke, activity daily living.

Hasil yang diperoleh peran keluarga sangat penting dalam proses kemandirian ADL pasien post stroke. Sumber daya yang dimiliki keluarga memberikan kontribusi besar terhadap proses adaptasi. Pemulihan pasien stroke membutuhkan koping positif dari keluarga. Sumber daya keluarga terdiri dari sumber daya internal, yaitu kesehatan fisik dan emosional, pendidikan, self efficacy, karakteristik kepribadian. Sumber daya external yaitu pelayanan dari fasilitas kesehatan, program home care dan layanan berbasis masyarakat.

Kesimpulan akhirnya adalah asuhan keperawatan secara holistik terhadap pasien post stroke beserta keluarganya mampu meningkatkan kemandirian pasien dalam melakukan ADL, sehingga pasien bisa mencapai kualitas hidup yang baik.
\end{abstract}

Kata Kunci: Stress family, Stroke, Activity Daily Living 
Jurnal IImu Keperawatan Medial Bedah 2 (1), Mei 2018, 1-54

ISSN 2338-2058 (print), ISSN 2621-2986 (online)

\section{PENDAHULUAN}

Stroke merupakan salah satu penyakit yang meninggalkan gejala sisa berupa kecacatan bagi penderitanya. Diperkirakan sepertiga dari jumlah penderita stroke di dunia mengalami kecacatan yang permanen (Dalvand, Ghanei Gheshlagh, \& Kurdi, 2018). Stroke memiliki efek besar bagi pasien dan keluarganya. Sekitar $80 \%$ pasien stroke bergantung pada keluarganya untuk memenuhi aktifitas sehari - harinya (Chafjiri, Navabi, Shamsalinia, \& Ghaffari, 2017). Sebuah study di Iran mengungkapkan bahwa $24-53 \%$ pasien stroke tidak mampu melakukan aktifitas sehari - hari secara mandiri.(Fallahi Khoshknab et al., 2016)

Serangan stroke terjadi secara tiba - tiba, sehingga keluarga harus bisa beradaptasi dengan

baik. Sebagian besar pasien stroke pulang dari rumah sakit sangat membutuhkan peran keluarga sebagai pengasuhnya. Semakin parah tingkat ketergantungan pasien stroke, semakin besar beban yang ditanggung oleh keluarga pasien. Kurangnya informasi yang diperoleh keluarga mengenai status kesehatan pasien stroke dan juga proses perawatan yang tidak jelas menyebabkan keluarga mengalami stress. Sumber stress yang dialami keluarga adalah kesenjangan antara keinginan keluarga dalam merawat pasien stroke dengan sumber daya fisik, psikologis dan keuangan keluarga. Menurut penelitian di Polandia sekitar 25 - 54\% keluarga mengalami stress pada tahun pertama setelah serangan stroke.(Jaracz, Grabowska-Fudala, Górna, \& Kozubski, 2014)

Hasil wawancara yang dilakukan penulis terhadap pasien stroke yang sedang menjalani rawat inap di RSUD Ungaran, mereka tidak mampu melakukan aktifitas sehari - harinya (ADL) secara mandiri. Keluarga pasien yang mendampingi juga merasa terbebani atas kondisi tersebut. Mereka terbebani dari segi ekonomi dan juga masalah perawatan pasien. Mereka tidak mengerti bagaimana cara merawat pasien setelah pulang dari rumah sakit. Selama ini proses intervensi terhadap pasien stroke hanya diberikan kepada pasien saja, keluarga tidak mendapatkan intervensi yang bisa meningkatkan keterampilan mereka dalam memberikan perawatan kepada pasien selama dirumah.

Menurut Orem (1991) asuhan keperawatan merupakan pemberian bantuan kepada pasien secara langsung agar pasien bisa melakukan perawatan secara mandiri, perawat juga membantu orang lain atau keluarga agar mampu merawat pasien secara mandiri (Mclaughlin Renpenning, Katherin \& Taylor,Susan.G, RN, PHD, 2003).Peran perawat sebagai edukator bertugas memberikan latihan kepada pasien stroke selama dirawat di rumah sakit tentang keterampilan mobilisasi, untuk meningkatkan kemampuan dalam melakukan aktifitas sehari-hari (ADL) secara Lestari / Pengaruh Pengelolaan Stress Keluarga Terhadap Activity Daily.... Page $\mathbf{3 8}$ of 54 
mandiri. Perawat juga perlu memberikan keterampilan kepada keluarga tentang perawatan pasien selama dirumah, karena menurut penelitan yang sudah ada, keluarga pasien stroke mengalami stress yang disebabkan mereka tidak siap melakukan perawatan terhadap pasien selama dirumah (Pesantes, Brandt, Ipince, Miranda, \& Diez-Canseco, 2017). Tujuan penulisan artikel ini untuk mendeskripsikan pengaruh pengelolaan stress keluarga terhadap kemandirian pasien post stroke iskemik.

\section{METODE PENELITIAN}

Metode yang digunakan dalam penulisan ini adalah literature review. Studi literatur ini menganalisa tentang pengelolaan stress keluarga pasien stroke dengan kemandirian pasien post stroke iskemik lalu dilakukan sintesa untuk mendeskripsikan pengaruh pengelolaan stress keluarga terhadap kemandirian ADL pasien post stroke iskemik. Sumber pustaka yang digunakan dalam penulisan ini adalah jurnal dan buku referensi yang terkait dengan stress keluarga pasien stroke dan kemandirian ADL pasien post stroke iskemik. Tahun penerbitan dari jurnal dan buku referensi yang digunakan dari tahun 2003 sampai tahun 2018. Kata kunci yang digunakan dalam mencari artikel atau jurnal adalah stress family, stroke, activity daily living.

\section{HASIL DAN PEMBAHASAN}

Stroke merupakan gangguan vaskulariasai pada otak yang datang secara tiba - tiba, menimbulkan gejala yang berlangsung secara menetap lebih dari 24 jam atau lebih, dan menimbulkan kecacatan hingga kematian. Jumlah penderita stroke menurut RISKESDAS 2018 mengalami peningkatan, jika pada tahun 2013 sebesar 7\%, maka pada tahun 2018 menjadi 10,9\%.

Stroke menjadi penyebab ketidakmampuan bagi penderitanya. Menurut Jeong (2018), 25 - 74\% dari lima puluh juta penderita stroke didunia tidak mampu melakukan aktifitas sehari - hari dengan mandiri (Jeong, Han, Jang, \& Lee, 2018). Ketidakmampuan tersebut bisa menyebabkan depresi pada pasien post stroke (Dong, Zhang, Tong, \& Qin, 2012). Pasien stroke perlu menjalani proses rehabilitasi sedini mungkin, karena selain meningkatkan kemampuan mobilitas, rehabilitasi secara dini juga bisa membantu pemulihan daerah penumbra di otak (Alexander, Sheila A, RN, 2013). Faktor yang mempengaruhi keberhasilan rehabilitasi pada pasien post stoke salah satunya adalah motivasi dalam diri pasien (Rapolienè, Endzelytė, Jasevičienė, \& Savickas, 2018). Motivasi terhadap pasien stroke selain dari dalam diri pasien sendiri juga di peroleh dari dukungan keluarga. 
Jurnal IImu Keperawatan Medial Bedah 2 (1), Mei 2018, 1-54

ISSN 2338-2058 (print), ISSN 2621-2986 (online)

Keluarga sangat berperan dalam proses rehabilitasi pasien post stroke (Hesamzadeh, Dalvandi, Bagher Maddah, Fallahi Khoshknab, \& Ahmadi, 2015).

Stroke mempengaruhi kualitas hidup penderitanya juga menjadi beban bagi keluarganya. Secara tidak formal keluarga menjadi pengasuh bagi pasien post stroke setelah mereka pulang dari rumah sakit. Hal ini menyebabkan tekanan fisik dan psikologis bagi keluarga (Pesantes et al., 2017). Sekitar 25\% - 54\% keluarga mengalami stress di tahun pertama terjadinya stroke (Jaracz et al., 2014). Setelah pasien pulang dari rumah sakit, keluarga sering tidak siap untuk melakukan perawatan mandiri terhadap pasien stroke dirumah karena mereka belum mendapatkan pengetahuan tentang stroke dari rumah sakit. Akibatnya keluarga merasa terbebani, mengalami gejala depresi hingga mengurangi kualitas hidup terkait kesehatan (Castaño \& Maurer, 2015). Kebanyakan keluarga yang merawat pasien post stroke di rumah mengalami kelelahan, kesepian, hingga depresi, sehingga kesehatan fisik dan mental berkurang dan kualitas mereka dalam merawat pasien stroke menjadi berkurang (Chafjiri et al., 2017).

Keluarga sebagai pengasuh pasien stroke sangat membutuhkan dukungan untuk mampu beradaptasi terhadap perubahan kondisi yang terjadi karena semakin tinggi tingkat kecacatan pasien stroke, semakin besar pula beban yang dialami keluarga. Sumber daya keluarga berkontribusi bessar terhadap proses adaptasi keluarga. Sumber daya keluarga terdiri dari sumber daya internal dan eksternal (Hesamzadeh et al., 2015). Sumber daya internal yaitu kesehatan fisik dan emosional, pendidikan, self efficacy, karakteristik kepribadian. Sedangkan sumber daya eksternal meliputi pelayanan dari fasilitas kesehatan, program home care dan layanan berbasis masyarakat.

Keluarga sebagai pengasuh pasien post stroke dirumah sangat membutuhkan intervensi untuk meningkatkan kemampuan mereka dalam beradaptasi, sehingga akan diperoleh koping yang positif (Clark et al., 2014). Jenis intervensi yang sering diberikan pada keluarga pasien stroke antara lain skill building, informasi psiko-edukasi dan support. Peran perawat sebagai edukator memiliki kewajiban memberi keterampilan kepada pasien untuk meningkatkan kemampuan mobilisasinya sehingga pasien dapat meningkatkan aktifitas sehari - harinya (ADL) secara mandiri. Selain itu keluarga pasien stroke juga perlu diberi intervensi untuk meningkatkan kemampuan mereka dalam memberikan asuhan kepada pasien stroke setelah pulang dari rumah sakit. Keluarga sebagai pengasuh pasien post stroke di rumah memiliki kebutuhan yang berbeda pada setiap tahap perkembangan penyakit pasien (Teh et al., 2018). Tahap akut penyakit stroke, Lestari / Pengaruh Pengelolaan Stress Keluarga Terhadap Activity Daily.... Page $\mathbf{4 0}$ of 54 
keluarga membutuhkan informasi tentang penyakit, perkembangan dan pengobatan penyakit. Tahap pertama (tahap akut) ini terjadi saat pasien menjalani rawat inap di rumah sakit. Keluarga pasien sangat mengharapkan mendapat informasi dari perawat tentang penyakit dan perkembangan kondisi pasien serta proses pengobatan yang harus dijalani pasien. Informasi tersebut bisa disampaikan oleh dokter ataupun perawat yang menangani pasien.apabila informasi tersebut tidak diperoleh keluarga akan menimbulkan kecemasan dan ketidakpastian. Tahap kedua yaitu tahap transisi, keluarga harus mempersiapkan perpindahan pasien dari perawatan dirumah sakit dengan perawatan dirumah. Termasuk kebutuhan dalam tahap ini respon emosional pasien, peralatan yang mendukung perawatan dirumah, manajemen obat, pencegahan penyakit pasien menjadi lebih parah dan ketersediaan sumber daya pasien. Tahap ini dipersiapkan perawat sebelum pasien pulang. Keluarga dipastikan terlebih dahulu keterampilan dan pemahamannya tentang perawatan pasien stroke selama dirumah. Tahap ketiga, yaitu beberapa bulan setelah serangan stroke, keluarga harus sudah bisa beradaptasi terhadap kondisi yang terjadi pada pasien stroke. Keluarga perlu informasi tentang perkembangan pasien, perhatian masalah finansial keluarga dan dukungan dari masyarakat sekitar. Perawatan pada tahap berbeda pada tiap pasien.

\section{KESIMPULAN}

Tahap akut penyakit stroke, keluarga membutuhkan informasi tentang penyakit, perkembangan dan pengobatan penyakit. Tahap kedua yaitu tahap transisi, keluarga harus mempersiapkan perpindahan pasien dari perawatan dirumah sakit dengan perawatan dirumah. Tahap ketiga, yaitu beberapa bulan setelah serangan stroke, keluarga harus sudah bisa beradaptasi terhadap kondisi yang terjadi pada pasien stroke. Kesimpulan akhirnya adalah asuhan keperawatan secara holistik terhadap pasien post stroke beserta keluarganya mampu meningkatkan kemandirian pasien dalam melakukan ADL, sehingga pasien bisa mencapai kualitas hidup yang baik.

\section{DAFTAR PUSTAKA}

Alexander, Sheila A, RN, P. (2013). Evidence-Based Nursing Care for Stroke and Neurovascular Conditions.

Castaño, A., \& Maurer, M. S. (2015). HHS Public Access, 20(2), 163-178. https://doi.org/10.1007/s10741-014-9462-7.Natural

Chafjiri, R. T., Navabi, N., Shamsalinia, A., \& Ghaffari, F. (2017). The relationship between the Lestari / Pengaruh Pengelolaan Stress Keluarga Terhadap Activity Daily.... Page 41 of 54 
Jurnal IImu Keperawatan Medial Bedah 2 (1), Mei 2018, 1-54

ISSN 2338-2058 (print), ISSN 2621-2986 (online)

spiritual attitude of the family caregivers of older patients with stroke and their burden. Clinical Interventions in Aging, 12, 453-458. https://doi.org/10.2147/CIA.S121285

Clark, P. C., Miller, E. L., Lutz, B. J., Kelly-Hayes, M., King, R. B., \& Bakas, T. (2014).

Evidence for Stroke Family Caregiver and Dyad Interventions. Stroke, 45(9), 2836-2852. https://doi.org/10.1161/str.0000000000000033

Dalvand, S., Ghanei Gheshlagh, R., \& Kurdi, A. (2018). Prevalence of poststroke depression in Iranian patients: a systematic review and meta-analysis. Neuropsychiatric Disease and Treatment, Volume 14, 3073-3080. https://doi.org/10.2147/NDT.S184905

Dong, J. Y., Zhang, Y. H., Tong, J., \& Qin, L. Q. (2012). Depression and risk of stroke: A metaanalysis of prospective studies. Stroke, 43(1), 32-37. https://doi.org/10.1161/STROKEAHA.111.630871

Fallahi Khoshknab, M., Mosavi Arfa, N., Ahmadi, F., Dalvandi, A., Hesamzadeh, A., \& Bagher Maddah, S. (2016). Family caregivers' experience of activities of daily living handling in older adult with stroke: a qualitative research in the Iranian context. Scandinavian Journal of Caring Sciences, 31(3), 515-526. https://doi.org/10.1111/scs.12365

Hesamzadeh, A., Dalvandi, A., Bagher Maddah, S., Fallahi Khoshknab, M., \& Ahmadi, F. (2015). Family adaptation to stroke: A metasynthesis of qualitative research based on double ABCX model. Asian Nursing Research, 9(3), 177-184.

https://doi.org/10.1016/j.anr.2015.03.005

Jaracz, K., Grabowska-Fudala, B., Górna, K., \& Kozubski, W. (2014). Caregiving burden and its determinants in Polish caregivers of stroke survivors. Archives of Medical Science, 10(5), 941-950. https://doi.org/10.5114/aoms.2014.46214

Jeong, H., Han, S. J., Jang, S. J., \& Lee, J. E. (2018). Factors Affecting Activities of Daily Living in Severely Disabled Stroke Patients. Brain \& Neurorehabilitation, 11(2). https://doi.org/10.12786/bn.2018.11.e11

Mclaughlin Renpenning, Katherin, M., \& Taylor,Susan.G, RN, PHD, F. (2003). Self - Care Theory in Nursing Selected Papers of Dorothea Orem.

Pesantes, M. A., Brandt, L. R., Ipince, A., Miranda, J. J., \& Diez-Canseco, F. (2017). An exploration into caring for a stroke-survivor in Lima, Peru: Emotional impact, stress factors, coping mechanisms and unmet needs of informal caregivers. ENeurologicalSci, 6, 33-50. https://doi.org/10.1016/j.ensci.2016.11.004 Lestari / Pengaruh Pengelolaan Stress Keluarga Terhadap Activity Daily.... Page $\mathbf{4 2}$ of $\mathbf{5 4}$ 
Jurnal IImu Keperawatan Medial Bedah 2 (1), Mei 2018, 1-54

ISSN 2338-2058 (print), ISSN 2621-2986 (online)

Rapolienė, J., Endzelytė, E., Jasevičienė, I., \& Savickas, R. (2018). Stroke Patients Motivation Influence on the Effectiveness of Occupational Therapy. Rehabilitation Research and Practice, 2018, 1-7. https://doi.org/10.1155/2018/9367942

Teh, W. L., Abdin, E., Vaingankar, J. A., Seow, E., Sagayadevan, V., Shafie, S., ... Subramaniam, M. (2018). Prevalence of stroke, risk factors, disability and care needs in older adults in Singapore: results from the WiSE study. BMJ Open, 8(3), e020285. https://doi.org/10.1136/bmjopen-2017-020285 